\title{
The Impact of Marketing Mix on the Consumer Purchase Decision in the Surabaya - Indonesia Hotel Residence
}

\author{
Qausar Eganael Putra ${ }^{1}$, Zeplin Jiwa Husada Tarigan ${ }^{1 *}$, Rismawati Br Sitepu ${ }^{2,3}$, and \\ Sanju Kumar Singh ${ }^{4}$ \\ ${ }^{1}$ Petra Christian University, Siwalankerto 121-131, Surabaya 60236, Indonesia \\ ${ }^{2}$ STIE Mahardhika Surabaya, Jl. Wisata Menanggal No.42A Surabaya 60234, Indonesia \\ ${ }^{3}$ Faculty of Economics and Business, Airlangga University, Jl. Airlangga No.4, \\ Surabaya 60286, Indonesia \\ ${ }^{\square}$ Tribhuvan University, Rd, Kirtipur 44618, Kathmandu, Nepal
}

\begin{abstract}
The hospitality business is rapidly growing and has caused fierce competition in this industry. It can be seen from the number of new hotels particularly for the 2 and 3-star hotels, and budget hotels in Surabaya. The hotels applied various strategies in acquiring new customers and retain loyal customers in the pursuit of a high level of occupancy in order to maintain business continuity. Performing appropriate marketing tactics is one of the ways to enable the hotel to increasing occupancy rates. Marketing strategy is associated with the products, prices, promotions, and distribution. This study aims at seeking the impact of the product, prices, promotion, and distribution on the consumer purchasing decisions. The population is all visitors to budget hotels located in the city of Surabaya. The data collection was conducted by distributing the self-administered questionnaire to 150 visitors. Of the 150,125 questionnaires were valid for further analysis. The sampling frame uses judgmental sampling techniques. Data processing used multiple linear regression using SPSS software. The results showed that hotel products have an influence on consumer purchasing decisions; prices have an influence on consumer purchasing decisions. The location of the hotel affects the purchase decision. Promotion performed by the hotel influence the purchase decision by the consumer. This research model needs to be developed by providing service process variables and employee competencies in hotels in Surabaya.
\end{abstract}

Keywords: Product, price, place, promotion, buyer decision.

\section{Introduction}

Hotel is a type of accommodation that utilizes a building to provide lodging, food and beverage, facilities, and other supporting services used for commercial activities (Minister of Tourism, Post \& Telecommunications Decree No. KM 37 / PW. 340 / MPPT-86). A city

* Corresponding author: zeplin@petra.ac.id 
hotel or commonly called a budget hotel, is a hotel that is used by consumers to stay temporarily or just for transit. Budget hotels are usually located in urban areas, and the majority of consumers are business people [1]. Hotels that focus on serving the budget segment are currently the most developed sectors. Its development led to a significant increase in the number of hotel providers and consumers' interest in the services provided by budget hotels [2]. Surabaya is one of the cities that is experiencing the growth in the hotel industry, particularly the budget hotels which are categorized as the two or three-star hotel.

Head of East Java Central Bureau of Statistics (BPS - Badan Pusat Statistik), Teguh Pramono [in 3] said that the occupancy rate of 2-star hotels in January 2017 reached $61.17 \%$ and was the highest occupancy rate compared to other star-rated hotel occupancy rates such as 3-star hotel with the occupancy rates of $58.13 \%$, followed by 4 -star hotels at $51 \%$, 5-stars hotel at $44.53 \%$, and one-star hotels by $39.08 \%$. The increase in hotel budget occupancy is influenced by the decisions made by consumers when renting a hotel room. Purchasing decisions is the evaluation stage of consumers in choosing based on preferences among several brands and possibly also from the intention to buy from the most preferred brand [4]. Purchasing decisions can only be made when there are several other alternatives to choose [5]. If there are no other alternatives that can be chosen, then there is no such thing as a purchasing decision. The price and brand image influence customer purchasing decisions on Samsung Smartphone products [6]. The price has an influence on customers in making purchasing decisions [7]. Service quality is also an essential aspect of a hotel company, where service quality is a product of the company [8]. The quality of customer service begins with a need from the customer and gets its satisfaction so that the customer can give a positive value to customer service rather than the company itself. Location factors also influence consumers in making decisions about buying goods and services [9]. If the location of the company is easily accessible to consumers and close to the downtown crowd, then it is the right thing for the company to determine a location where the company will operate [10]. Another aspect is a promotion, which is a communication activity between seller and buyer and is an activity that helps the buyer in deciding on the marketing field. The promotion influences consumers in making purchasing decisions [11]. Based on the above discussion, this paper examines the impact of marketing mix on the consumer purchase decision in the Surabaya hotel residence

\section{Theoretical review}

Marketing mix can be interpreted as a set of controlled marketing tools implemented by several companies to get the desired response in the target market [12]. These tools have four parts and are commonly called 4Ps, which include Product, Price, Place, and Promotion. Products are goods or services offered and sold by companies to prospective customers. Price is the nominal amount of money that the customer must pay to get the product. A place is a place where the company carries out its activities and the place where a company operates in processing goods and services. The last is promotion is an activity carried out by the company to communicate the benefits and uses of a product or service produced by the company to attract the interest of prospective customers to buy the product.

\subsection{Customer service (hotel product)}

Product is a product and service that can be offered by producers to prospective consumers to be noticed, requested, sought and bought and used by the market to meet the needs and desires of the relevant market. Products offered by companies can include products or services so that products can be tangible or intangible. Products have the meaning as 
everything that can be offered to the market to get attention, use, acquisition, or consumption that can meet the needs and desires of customers. Characteristics of products and services are also influenced by the ability of goods or services to be able to meet customer needs and be able to satisfy them or not [12]. In hospitality, the value of a product is a customer service or a service. Products are everything in the form of goods and services that can be offered to the market for consumption that can meet customer needs [12]. Therefore, service is an intangible activity that exists due to interactions between consumers and employees of the company to provide what consumers need. The quality of service products provided by hotels to customers are reliability, responsiveness, assurance, empathy, and tangibles [13]. The quality of service products provided by restaurants to their customers is related to Reliability, Responsiveness, Assurance, Empathy, and Tangibles [14].

\subsection{Price}

Price is defined as the nominal amount of money that must be paid to obtain a product or service, or the amount of value that consumers exchange to obtain benefits and use a product or service [12]. Price is the most straightforward element in a marketing program to adjust. The price is a condition for payment on products that are following the ability of consumers to pay [6]. Seeing from the above quote, it can be seen that the price can be referred to as the overall value of an item that we have to pay with a certain amount of money to get an ownership right. Although the price is not a significant factor in determining the selection of services or the purchase of a product but selling prices that are too high can make consumers turn to the use of goods or services provided by competitors.

Prices can help customers to decide on the ability to allocate their purchasing power to various types of products and services [6]. Quality company's product will provide a deal with the price of the product offered so that it impacts on the customer's decision to buy or not, but for the company, it results in profit loss. Indicator for variable price there are four measures that characterize prices, including price affordability, price according to ability and competitiveness, price conformity with product quality, and price for benefit [12].

\subsection{Place}

A location is a place where a company or company activities carried out. Location is defined as a place for a company to operate and carry out all company activities [15]. The place is the company's activity to select, manage, and make a product in order to deliver products and services to the target market [12]. The location of a service company depends on the services of that company, some have a physical site, or some are only electronic. An essential factor in a business is a strategic location, especially in the hospitality sector. Companies must pay attention to how easy it is for customers to access these locations and are located in a very strategic place.

\subsection{Promotion}

Promotion is a company's activity in communicating the advantages of a product or service, to persuade the target market to buy the product. Although the product produced by the company is the right quality product, if people have never seen and heard this product, then they will not be sure of the product [6]. Promotion is one of the variables in the marketing mix that is important for a company to market its service products [15]. The promotion does not only function for communication activities with consumers but also to influence to use service products according to the needs and desires of consumers [16]. 


\subsection{Buying decision}

Purchasing decisions can only be made when there are several other alternatives that can be chosen so that someone makes a purchase or not [17]. If there are no other alternatives to choose from, there is no such thing as a purchase decision. The purchase decision process has five stages carried out by the customer before it can decide on a purchase and subsequently post-purchase [12]. Purchase decisions made by the customer can occur when the customer has received service from the provision of services, and then the customer can feel satisfaction or dissatisfaction, and therefore, the purchase decision can still be related to customer satisfaction. In making a purchase decision that is with the stability of a product, the habit of buying products, providing recommendations to others, and making repeat purchases.

\subsection{Relationship between research concepts}

The product has a significant effect on a purchasing decision [14]. The quality of a product is the conformity of the needs and desires of a product into a product specification produced [13]. The quality of products marketed by companies is one of a variety of elements that must be paid more attention to the company if the company wants to win the competition [16]. This can be evidenced from previous research that purchasing decisions are influenced by the products, of course, consumers will not buy a product if the product does not meet expectations and states that the product influences purchasing decisions. Based on this review, the first hypotheses are proposed.

H1: Products influence on purchasing decisions.

Determining a price on a product is one of the most critical decisions for a company [17]. One of the principles for companies when determining prices is to focus on the desire to buy customers for a price that is determined by the appropriate amount in closing costs and generate profits [15]. Prices can affect purchasing decisions from customers, prices have an influence on customers in making purchasing decisions [7]. Hence, the second hypotheses are as follows:

$\mathrm{H} 2$ : Price has a positive and significant influence on purchasing decisions

Location in the right marketing mix is a location that provides fast access and can attract large consumers and can change purchasing patterns to consumers [15]. The right location can make it easier for prospective customers to meet their needs and provide benefits for the company to influence a purchasing decision [6]. The success of a company is undoubtedly influenced by the location of the company. Consumers will consider purchasing by looking at the location because if the location is strategic, it will also be related to the customer's buying decision on the product. The following hypotheses are proposed;

H3: Location has a positive and significant influence on purchasing decisions

Promotion is communication between companies to prospective customers by conveying information from products offered with the aim that prospective customers know about their products. The promotion is a variable of the marketing mix that is very important for companies to introduce their products to the market by advertising or other 
activities aimed at driving product demand [6]. Factors that influence purchasing decisions related to feelings and emotions, if someone feels satisfied in buying a product that will strengthen buying interest. It can also be concluded that promotion is very influential in customer purchasing decisions. Therefore, the company must make the best and most efficient promotion possible to attract their hearts. The fourth hypotheses are as follow: H4: Promotion has a positive and significant influence on purchasing decisions.

\section{Research methods}

Quantitative research is used to examine populations from the result of specific samples. This study uses the purposive sampling technique where data collection using the instrument of a questionnaire and following by statistical data analysis to test the hypothesis. Quantitative research also means survey research conducted by giving questions and recording answers. The population of this study is consumers who have made a purchase (stay) at a hotel in the city of Surabaya. The method in this study uses purposive sampling, that applied a specific consideration in determining the sample. The sample criteria are those customers who were at least $17 \mathrm{yr}$ old, categorized as adults and could understand the contents of the questionnaire, and had made a purchase (stay) at a Surabaya city hotel at least once in the past one year (April 2018) until April 2019).

The data collection technique used was a questionnaire with a Likert scale, and the questionnaire was closed, i.e., respondents gave answers following the implementation through the answers that have been determined. This model aims to see the direct effect of independent variables on the dependent variable using multiple linear regression [18].

\section{Analysis and discussion}

The total amount of respondent data that can be used is 125 samples. The following descriptive analysis was conducted using respondent characteristics based on gender and age. Female respondents numbered 73 people or $58.4 \%$, while male respondents numbered 42 people or $41.6 \%$. Research respondents were predominantly aged $18 \mathrm{yr}$ to $25 \mathrm{yr}$, with 83 people $(66.4 \%)$, aged $26 \mathrm{yr}$ to $40 \mathrm{yr}$ with seven people $(5.6 \%)$, and over $40 \mathrm{yr}$ of age with 35 people $(28 \%)$.

The normality test results with the typical probability plot show that the data is spread around the diagonal line. Furthermore, the Kolmogorov Smirnov test results show a significance value $>0.05$ which is equal to 0.261 . Based on available data, it can be concluded that the regression model residuals are normally distributed. VIF value and tolerance for each variable that has fulfilled the requirements that should be VIF results below 10 and tolerance value $>0$. Through the table, it is concluded that in the regression model, multicollinearity does not occur. The heteroscedasticity test is done by looking at scatterplot charts. Regression models are stated to meet the assumption of heteroscedasticity if the points on the scatterplot graph spread and do not form a particular pattern [19]. The heteroscedasticity test was strengthened with the glacier test between the independent variables and the residual value. The table shows that the significance value of the glacier test of the independent variables is stated to meet heteroscedasticity because of the significance value $>0.05$. By fulfilling the previous tests, it can be done multiple linear regression tests.

Multiple linear regression analysis is used to see the dependent variable if the independent variable is raised or lowered. Multiple linear regression analysis was conducted to examine the simultaneous effect of four independent variables on the dependent variable (Table 1). 
Table 1. Coefficient of determination

\begin{tabular}{|c|c|c|c|c|}
\hline Model & R & R Square & Adjusted R Square & $\begin{array}{c}\text { Std. The error of the } \\
\text { Estimate }\end{array}$ \\
\hline 1 & $0.855^{\mathrm{a}}$ & 0.731 & 0.722 & 0.358 \\
\hline
\end{tabular}

The coefficient of determination $\mathrm{R}^{2}$ is 0.731 . This shows that the ability of Product (X1), Price (X2), Location (X3) and Promotion (X4) variables have an influence on the Purchase Decision variable (Y) of $73.1 \%$, the influence is judged to be strong with an Rvalue of 0.855 i.e., at above 0.5 while the remaining $26.9 \%$ is the influence of other independent variables not examined. The model feasibility test used the F test (Table 2).

Table 2. F-test

\begin{tabular}{|l|c|c|c|c|c|}
\hline \multicolumn{1}{|c|}{ Model } & Sum of Square & Df & Mean Square & F & Sig. \\
\hline Regression & 41.621 & 4 & 10.405 & 81.364 & $0.000^{\mathrm{b}}$ \\
\hline Residual & 15.346 & 120 & 0.128 & & \\
\hline Total & 56.967 & 124 & & & \\
\hline
\end{tabular}

The results of the calculation shown in Table 2. it can be seen that the F value is 81.336, with the significance value is 0.000 . This value indicates a significance value of less than $0.05(\alpha=5 \%)$. From the results obtained, it was concluded that simultaneously Product (X1), Price (X2), Location (X3), and Promotion (X4) variables had a significant effect on the Purchase Decision variable (Y). Partial effect tests are listed in Table 3.

Tabel 3. Partial test

\begin{tabular}{|c|c|c|c|c|c|}
\hline \multirow{2}{*}{ Model } & \multicolumn{2}{|c|}{ Unstandardized Coefficients } & $\begin{array}{c}\text { Standardized } \\
\text { Coefficients Beta }\end{array}$ & t & Sig. \\
\cline { 2 - 3 } & $\mathbf{B}$ & Std. Error & & 0.515 & 0.607 \\
\hline Constant) & 0.123 & 0.239 & 0.326 & 3.027 & 0.003 \\
\hline $\mathrm{X}_{1}$ & 0.337 & 0.111 & 0.208 & 2.322 & 0.022 \\
\hline $\mathrm{X}_{2}$ & 0.227 & 0.098 & 0.186 & 2.033 & 0.044 \\
\hline $\mathrm{X}_{3}$ & 0.196 & 0.096 & 0.212 & 2.265 & 0.025 \\
\hline $\mathrm{X}_{4}$ & 0.228 & 0.101 & &
\end{tabular}

Based on the t-test data shown in Table 3, it is known that the Product variable (X1) shows a significance value of $0.003<0.05$ so that it can be concluded if the hypothesis is accepted. This shows if the Product variable significantly influences the Purchase Decision variable. In a study conducted by Djatmiko and Pradana [6] said if a product has a significant effect on a purchasing decision. The quality of a product is the conformity of the needs and desires of a product into a product specification produced [13]. The quality of the products marketed by the company is one of a variety of elements that must be given more attention to the company if the company wants to win the competition. This can be evidenced from previous research that purchasing decisions are influenced by products; of course, consumers will not buy a product if the product does not meet expectations and states that the product influences purchasing decisions.

Table 3, which displays the results of the t-test, shows that the Price variable (X2) has a significance value of $0.022<0.05$, which indicates the hypothesis is accepted. This means that the Price variable has a significant effect on the Purchase Decision variable. Determining a price on a product is one of the most critical decisions for a company. One of the principles for companies when determining prices is to focus on the desire to buy 
customers for a price that is determined by the appropriate amount in closing costs and generating profits [17]. Prices can affect purchasing decisions from customers, the prices have an influence on customers in making purchasing decisions [7].

Table 3, which shows the results of the t-test, shows that the Location variable (X3) has a significance value of $0.044<0.05$, which indicates the hypothesis is accepted. This means that the Location variable has a significant influence on the Purchase Decision variable. The good location is a location that provides fast access and can attract large consumers and can change purchasing patterns to consumers [6]. The right location can make it easier for prospective customers to meet their needs and provide benefits for the company to influence a purchasing decision [15]. The success of a company is undoubtedly influenced by the location of the company. Consumers will consider purchasing by looking at the location because if the location is strategic, it will also be related to the customer's buying decision on the product. So based on the above research, it can be concluded that location influences purchasing decisions

Table 3, which displays the results of the t-test, shows that the Promotion variable (X4) has a significance value of $0.025<0.05$, which indicates the hypothesis is accepted. This means that the Promotion variable has a significant influence on the Purchase Decision variable. Promotion is communication between companies to prospective customers by conveying information from products offered with the aim that prospective customers know about their products. The promotion is a variable of the marketing mix, which is very important for companies to introduce their products to the market by advertising or other activities aimed at driving product demand [16].

\section{Conclusions}

Based on the results of the analysis, the researcher can draw the following conclusions: first, the product has a positive and significant effect on Purchasing Decisions on Hotel Customers in Surabaya. Second, the price has a positive and significant effect on Purchasing Decisions on Hotel Customers in Surabaya. The third Location has a positive and significant influence on Purchasing Decisions on Hotel Customers in Surabaya. Fourth Promotion has a positive and significant effect on Purchasing Decisions on Hotel Customers in Surabaya. Product, price, location, and promotions have an impact on hotel selection decisions in Surabaya. Companies need to provide training to employees to better perform maximum service, especially in serving answering hotel guest questions.

\section{References}

1. H. Luo, Y. Yang, International Journal of Hospitality Management, 59:72-83(2016). https://www.sciencedirect.com/science/article/pii/S0278431916302353

2. J. Peng, X. Zhao, A.S. Mattila, International Journal of Hospitality Management, 59,139-148(2015). https://www.sciencedirect.com/science/article/pii/S027843191500095X

3. A.S. Rini, Okupansi hotel bintang di Jatim 53.74\%. [Occupancy of star hotels in East Java was $53.74 \%$ ], [Online]

https://ekonomi.bisnis.com/read/20170331/107/641810/okupansi-hotel-bintang-dijatim-5374 (2017), [in Bahasa Indonesia], [Accessed on 18 April 2019].

4. S.A. Sofi, F.A. Nika, Arab Economics and Business Journal, 12,1:29-43(2017). https://www.sciencedirect.com/science/article/pii/S2214462516300834

5. A.F. Manampiring, I. Trang, Jurnal Emba, 4,1:72-483(2016). [in Bahasa Indonesia]. https://ejournal.unsrat.ac.id/index.php/emba/article/view/11637 
6. T. Djatmiko, R. Pradana, Procedia-Social and Behavioral Sciences, 219:221227(2016). https://www.sciencedirect.com/science/article/pii/S1877042816300696

7. S. Oetama, Jurnal Emba, 4,1:71-80(2011). [in Bahasa Indonesia]. http://arthavidya.wisnuwardhana.ac.id/index.php/arthavidya/article/viewFile/20/17

8. T. Sufi, N. Shojaie, Quality Services and Experiences in Hospitality and Tourism, 9:229-244(2018). https://www.emerald.com/insight/content/doi/10.1108/S2042$\underline{144320180000009016 / \mathrm{full} / \mathrm{html}}$

9. R. Lado-Sestayo, M. Vivel-Búa, Journal of Hospitality and Tourism Technology, 9,3:455-470(2018). https://www.emeraldinsight.com/doi/abs/10.1108/JHTT-10-20170118

10. B. Marco-Lajara, E. Claver-Cortés, M. Úbeda-García, International Journal of Contemporary Hospitality Management, 26,8:1312-1340(2014). https://www.emeraldinsight.com/doi/abs/10.1108/IJCHM-07-2013-0319

11. H. Huang, Y. Chang, C. Yeh, C. Liao, International Journal of Contemporary Hospitality Management, 26,7:1065-1082(2014). https://www.emeraldinsight.com/doi/abs/10.1108/IJCHM-05-2013-0204

12. P. Kotler, G. Armstrong, Principles of Marketing, New Jersey: Pearson Prentince Hall(2018). Kotler/dp/013449251X https://www.amazon.com/Principles-Marketing-17th-Philip-

13. N.M. Stefano, N.C. Filho, R. Barichello, A.P. Sohn, Procedia CIRP, 30:433438(2015). https://www.sciencedirect.com/science/article/pii/S2212827115004539

14. M.S. Omar, H.F. Ariffin, R. Ahmad, Procedia-Social and Behavioral Sciences, 224:384-392(2016). https://www.sciencedirect.com/science/article/pii/S1877042816304748

15. I. Azzadina, A.N. Huda, C.P.M. Sianipar, Procedia-Social and Behavioral Sciences 65:352-357(2012).

https://www.sciencedirect.com/science/article/pii/S187704281205118X

16. K. Wongleedee, Procedia-Social and Behavioral Sciences 197:2080-2085(2015). https://translateyar.ir/wp-content/uploads/2018/12/10.1016 j.sbspro.2015.07.323.pdf

17. R.M. Serrano, M.R.G. Ramírez, J.L.G. Gascó, European Research on Management and Business Economics, 24,3:137-148(2018).

https://www.sciencedirect.com/science/article/pii/S2444883418300998

18. Sugiyono, Metode Penelitian Pendidikan: Kuantitatif, Kualitatif dan R\&D. [Educational research methods: quantitative, qualitative and R\&D], Bandung: Penerbit Alfabeta, (2017). [in Bahasa Indonesia]. https://mjseoseoem.netlify.com/buku-sugiyono-2017-metode-penelitian-pdf.html

19. I. Ghozali, Aplikasi analisis multivariate dengan program IBM SPSS 23. [Multivariate analysis application with the IBM SPSS 23 program]. Semarang: Badan Penerbit Universitas Diponegoro (2016).[in Bahasa Indonesia]. http://eprints.umpo.ac.id/3770/7/daftar\%20pustaka.pdf 